\title{
Живое наследие
}

(Рецензия на книгу: Ванникова Н.И. Избранные лекции. Зарубежная литература Средних веков и Возрождения и XVII-XVIII веков / соред., сост. Н.Э. Микеладзе, М.Ю. Игнатьева (Оганисьян). М.: ИКАР; Фак. журн. МГУ, 2020)

\section{Инна Гуляева}

DOI: 10.30547/mediaalmanah.6.2020.285287

(C) Гуляева Инна Борисовна кандидат филологических наук, доцент кафедры зарубежной журналистики и литературы факультета журналистики МГУ имени М.В. Ломоносова (г. Москва, Россия), in.gulyaewa@yandex.ru
Нинель Ивановна Ванникова работала на факультете журналистики МГУ имени М.В. Ломоносова более полувека и была одним из самых выдающихся и уважаемых лекторов. Многие годы она преподавала дисциплины «История зарубежной литературы Средних веков и Возрождения» и «История зарубежной литературы XVII-XVIII веков». Но при этом Нинель Ивановна не стремилась написать учебник по этим курсам. Она издала только небольшое учебно-методическое пособие по зарубежной литературе Средних веков и Возрождения (Ванникова, 2014), а также участвовала в создании учебника (Ванникова, Засурский, Микеладзе, 2008) и учебно-методического пособия (Засурский, Микеладзе, Ванникова, 2008) по литературе XX в. Нинель Ивановна чрезвычайно ответственно относилась к подготовке учебного материала. (Знаю это хотя бы по тому, как тщательно она рецензировала мое учебно-методическое пособие для иностранных студентов, как выверяла в нем каждое слово.) Плоды научной мысли Н.И. Ванниковой были сосредоточены в первую очередь в ее лекциях, в том, что она отдавала своим слушателям. К счастью, в последний год ее преподавания эти лекции были записаны студентами, а теперь изданы в виде сборника ее учениками и коллегами - Н.Э. Микеладзе и М.Ю. Игнатьевой (Оганисьян). 
Составителям пришлось проделать большую и сложную работу. Необходимо было выверить расшифровки записей, сделанных студентами, найти источники цитат, приводимых лектором. Кроме этого потребовалось еще восстановить текст некоторых лекций, которые не были записаны. Для этого использовались конспекты студентов и рукописи самой Нинели Ивановны. Необходимо отметить тщательную, вдумчивую и бережную работу Н.Э. Микеладзе и М.Ю. Игнатьевой (Оганисьян) с этими материалами.

Рецензируемый сборник избранных лекций состоит из двух разделов, соответствующих двум периодам в истории зарубежной литературы. Первый раздел посвящен литературе Средних веков и Возрождения, второй - литературе XVII-XVIII вв. Оба этих исторических периода достаточно трудны для восприятия читателей нашего времени, в особенности молодых людей, студентов первого и второго курсов.

В лекциях Н.И. Ванниковой развитие литературы рассматривается в контексте общественных процессов. Курс лекций она всегда начинала с подробной характеристики исторического периода, специфики мировоззрения людей того времени, господствующих философских учений. Это помогало студентам проникнуться духом эпохи, понять образ мысли людей, живших в совсем иных условиях. В то же время Нинель Ивановна неустанно повторяла на своих занятиях, что рассматривать великие произведения литературы только в контексте их эпохи, через призму восприятия их современниками - значит обеднять эти произведения. Шедевры литературы потому и являются таковыми, что каждое новое поколение читателей находит в них новый, созвучный своему времени смысл.

Поэтому и лекции Н.И. Ванниковой не оставались неизменными на протяжении многих лет ее работы на факультете журналистики. Происходили перемены в общественной и научной мысли, менялись трактовки эпох и эстетических направлений (особенно Возрождения и барокко), появлялись новые филологические труды. Конечно, мы не можем проследить изменения в лекциях Н.И. Ванниковой только на основании текстов, опубликованных в сборнике. Но обратим внимание, что Нинель Ивановна упоминает в них литературоведческие работы, изданные в разное время, от 1950 гг. до 2000 гг. Она всегда внимательно следила за появлением новых научных публикаций и некоторые идеи использовала в своих лекциях, обязательно ссылаясь при этом на первоисточник. Благодаря ей студенты знакомились с работами таких замечательных ученых, как С.С. Аверинцев, А.А. Аникст, М.М. Бахтин, А.Я. Гуревич, Е.М. Мелетинский, Р. Менендес-Пидаль, Л.Е. Пинский и многие другие.

При этом Н.И. Ванникова на своих лекциях давала студентам не «истину в последней инстанции", а пищу для размышлений. Ей чужд был схоластический принцип внедрения в «неокрепшие умы» только неоспоримых идей и тезисов. Нинель Ивановна не считала нужным скрывать от своих учеников спорные вопросы литературоведения, не стеснялась возражать маститым филологам и опровергать утверждения из учебников. Так, например, в лекции о народной эпической поэзии раннего Средневековья она объясняет свое несогласие с мнением А.Я. Гуревича по поводу того, к какой эпохе следует отнести «Старшую Эдду» (с. 16)ㄹ. А рассказывая о литературе XVIII в., разъясняет студентам спор вокругтермина «просветительский реализм» (с. 303-305).

В лекциях Н.И. Ванниковой теоретические обобщения сочетаются с подробным анализом содержания произведения, обильным цитированием, помогающим выявлять смысл каждого эпизода, каждой детали литературного текста. Когда времени лекции не хватало для такого тщательного разбора, произведение выносилось на коллоквиум, где студенты уже непосредственно включались в процесс анализа текста. 
Эти занятия продолжались зачастую не одну академическую пару. В сборник включена запись одного из таких коллоквиумов, посвященных великим трагедиям Шекспира.

После того, как в учебном плане количество часов на изучение зарубежной литературы XVII-XVIII вв. было сокращено вдвое, Н.И. Ванникова искала и находила разные способы компенсировать нехватку времени и дать студентам необходимый материал насколько возможно в большем объеме. Во втором разделе сборника есть две главы, скромно названные «Консультация 1" и «Консультация 2». Каждая из них содержит в себе более или менее развернутые комментарии сразу к нескольким произведениям и темам, на которые не хватило времени в основном курсе лекций. Это пример изобретательности Нинели Ивановны и одновременно твердости ее принципов. Она не соглашалась сокращать объем изучаемого литературного материала или рассматривать его бегло, поверхностно. Мне кажется, что нынешний дистанционный формат обучения Нинель Ивановна тоже смогла бы успешно использовать для более широкого просвещения студентов.
Особенно значимым представляется то, что в сборнике опубликованы именно расшифровки записей лекций. Это позволило сохранить в них ощущение живой речи, характерные интонации Нинели Ивановны. И при этом - ясность и четкость формулировок, замечательно чистый и богатый литературный язык. Это не результат работы редакторов. Полагаю, в этом отношении им мало что приходилось править в расшифровках записей лекций. Нинель Ивановна всегда (не только на лекциях) говорила неторопливо, будто взвешивая каждое слово, проверяя его точность. И всегда в ее речи мысль была выражена максимально отчетливо и определенно.

Несмотря на то, что Н.И. Ванниковой больше нет с нами, ее наследие по-прежнему сохраняет свою ценность. Изданный сейчас сборник лекций будет еще долго богатым источником знаний для студентов и подспорьем для преподавателей, ведущих занятия по зарубежной литературе.

В январе 2021 г. будет 90 -летие со дня рождения Н.И. Ванниковой. И выпуск сборника ее лекций, на мой взгляд, достойное выражение нашего общего уважения и нашей памяти.

\section{Примечания}

1 Здесь и далее книга Ванниковой Н.И. «Избранные лекции. Зарубежная литература Средних веков и Возрождения и XVII-XVIII веков» цитируется с указанием страницы в круглых скобках.

\section{Библиография}

Ванникова Н.И. Учебно-методическое пособие по истории зарубежной литературы Средневековья и Возрождения. М.: Изд-во Моск. ун-та, 2014.

Ванникова Н.И., Засурский Я.Н., Микеладзе Н.Э. Зарубежная литература двадцатого века. М.: Изд-во Моск. ун-та, 2008.

Засурский Я.Н., Микеладзе Н.Э., Ванникова Н.И. Зарубежная литература XX века (1914-2000): учеб.-метод. пособие. М.: Изд-во Моск. ун-та, 2008. 